\title{
The Effects of Suburethral Tape on the Symptoms of Overactive Bladder
}

\author{
Die Wirkung des suburethralen Bandes auf die Symptome \\ der überaktiven Harnblase
}

Authors

Affiliation
G. Hensel, M. Koštál, J. Göbel

Department of Obstetrics and Gynaecology, Pardubická krajská nemocnice, a. s., Pardubice, Czech Republic
Key words

urinary incontinence

- urodynamics

- overactive bladder

- suburethral sling

Schlüsselwörter

- Harninkontinenz

- Urodynamik

- überaktive Harnblase

- suburethrales Band

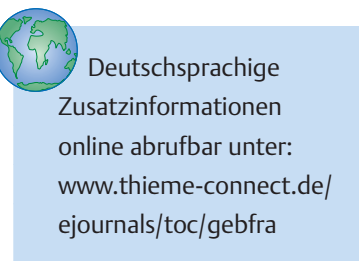

$\begin{array}{ll}\text { received } & 17.12 .2012 \\ \text { revised } & 22.5 .2013 \\ \text { accepted } & 11.10 .2013\end{array}$

Bibliography

Dol http://dx.doi.org/

10.1055/s-0033-1351073

Published online 21.1.2014

Geburtsh Frauenheilk 2014; 74

63-68 ๑ Georg Thieme

Verlag KG Stuttgart · New York . ISSN 0016-5751

\section{Correspondence}

\section{Dr. Germund Hensel}

Pardubická krajská nemocnice,

a.s.

Department of Obstetrics

and Gynaecology

Kyjevská 44

53203 Pardubice

Czech Republic

germund.hensel@seznam.cz

\section{Abstract \\ $\nabla$}

Suburethral tension-free vaginal tape is used for the treatment of stress urinary incontinence with a high success rate. Often patients report having stress incontinence, as well as co-existing micturition problems which are attributable to overactive bladder syndrome $(\mathrm{OAB})$. The present study examines the effect of suburethral tape on the symptoms of OAB. In the study, we used the transobturator vaginal tape inside-out technique (TVT-O).

Materials and Methods: 53 patients were included in the study, all had proven urodynamic stress incontinence and symptoms of overactive bladder. The patients were examined preoperatively and 3 months after the TVT-O placement. Results: The individual OAB symptoms improved significantly, with urinary frequency and urge incontinence improving more than nocturia. The frequency of micturition decreased on average from 16.1 to 10.1 episodes/24 hours, while nocturnal frequency of micturition decreased from 2.2 to 1.1. Not a single patient experienced the simultaneous worsening of all three measured variables, however $19 \%$ of patients did report their simultaneous disappearance. Their quality of life that had been affected by OAB was measured on the basis of validated questionnaires, and found to have improved significantly. Only $28 \%$ of patients reported a desire for drug treatment of OAB symptoms following tape placement.

Conclusions: TVT-O placement leads to a significant improvement of the symptoms of overactive bladder syndrome. Patient quality of life - which was affected by OAB - was also enhanced by the tape placement. This accounts for a substantial share of the overall success of the suburethral tape.

\section{Zusammenfassung \\ $\nabla$}

Das spannungsfreie suburethrale Vaginalband wird zur Behandlung der Belastungsinkontinenz mit hohen Erfolgsraten eingesetzt. Oft berichten Patientinnen mit Belastungsinkontinenz aber auch von gleichzeitig bestehenden Miktionsproblemen, die dem Syndrom der überaktiven Harnblase (engl. overactive bladder - OAB) zuzuordnen sind. Die vorliegende Studie prüft die Wirkung des suburethralen Bandes auf die Symptome der OAB. In der Studie verwendeten wir ein transobturatorisch geführtes Band in der Inside-outTechnik (TVT-O).

Material und Methoden: In die Studie wurden 53 Patientinnen eingebracht, die alle außer einer urodynamisch nachgewiesenen Belastungsinkontinenz Symptome der überaktiven Harnblase aufwiesen. Die Patientinnen wurden präoperativ und 3 Monate nach Implantation von TVT-O untersucht.

Ergebnisse: Die einzelnen OAB-Symptome verbesserten sich signifikant, Dranginkontinenz und Pollakisurie mehr als Nykturie. Die Miktionsfrequenz sank im Mittel von 16,1 auf 10,1 Miktionen/24 Stunden, die nächtliche Miktionsfrequenz von 2,2 auf 1,1. Bei keiner einzigen Patientin kam es zur gleichzeitigen Verschlechterung aller 3 gemessenen Parameter, dafür jedoch bei 19\% der Patientinnen zu ihrem gleichzeitigen Verschwinden. Die durch die OAB beeinträchtigte Lebensqualität verbesserte sich signifikant, was anhand von validierten Fragebögen gemessen wurde. Nur 28\% der Patientinnen gaben nach Bandeinlage noch den Wunsch nach medikamentöser Behandlung der OAB-Symptome an.

Schlussfolgerungen: Die Implantation von TVT-O führt zur signifikanten Verbesserung der Symptome der überaktiven Harnblase. Auch die durch die $O A B$ beeinträchtigte Lebensqualität wird durch die Bandimplantation gesteigert, was einen we- 
sentlichen Anteil am allgemeinen Erfolg des suburethralen Bandes ausmachen dürfte.

\section{Introduction}

The placement of suburethral tape is taking place all over the world with great success in the treatment of stress urinary incontinence. In many cases, however, upon closer anamnestic investigation, stress incontinence is found not to be the patient's only micturition problem. Often, the patient also has symptoms of an overactive bladder, which include urgency, frequency, nocturia and possibly urge urinary incontinence. If the patient suffers from a combination of stress and urge incontinence, this is defined by the International Continence Society (ICS) as mixed incontinence [1], which has, according to Dooley et al. [2] a prevalence of $30 \%$ of all women with urinary incontinence and is more of a strain on the patient than pure stress incontinence [3].

Several studies have already dealt with the question of whether mixed incontinence can be an indicator for surgical treatment. This question has now been answered with yes [4-6], although a lower cure rate is to be expected than in the case of pure stress incontinence [4]. Abdel-fattah [7] quotes a subjective rate of satisfaction of $75 \%$ of all patients with mixed incontinence one year after tape placement. In a meta-analysis, Jain [8] reports the cure rate of the urge urinary incontinence component to be $30-85 \%$ after tape placement. Kissling [6] proves that tape placement is superior in the case of mixed incontinence with a predominantly urge incontinence component to drug therapy with an anticholinergic.

In addition to its effect on urge incontinence, how much influence does tape placement have on the other individual symptoms of overactive bladder mentioned above? Athanasiou [9] describes how these are also significantly improved by tape placement. Abdel-fattah [7] reports a cure rate of $52 \%$ with respect to urgency, while Palva and Nilsson [10] quote a $61 \%$ cure rate for urinary frequency. Only $16-26 \%$ of patients wanted further drug treatment with antimuscarinics following tape placement $[11,12]$.

The present study aims to improve clarity about the extent to which the individual, preoperative, existing symptoms of overactive bladder syndrome are alleviated or cured, and how the related quality of life is improved by the placement of a suburethral tape.

\section{Materials and Methods}

\section{$\nabla$}

The present study is a prospective clinical longitudinal study. Changes to micturition variables and questionnaire scores are measured with reference to the symptoms of an overactive bladder. As the study has the character of an observational study and the indication for treatment (tape placement) in all patients was on the basis of a proven stress incontinence component, an ethics commission vote was not needed.

\section{Patient group}

The prospective observational study was conducted between June 2010 and June 2012 at the Department of Obstetrics and Gynaecology at Pardubice District Hospital (Pardubická krajská nemocnice, a.s.) in the Czech Republic. We studied 78 patients, to whom the inclusion criteria "proven urodynamic stress incon- tinence" and "concurrent symptoms of an overactive bladder" applied. All 78 patients had urge sensation, frequency (> 8 episodes of micturition/day) and nocturia, with some also having the symptom of urge urinary incontinence. The patients agreed to surgical treatment and all received the transobturator vaginal tape inside-out technique (TVT-0). For the study, the following exclusion criteria applied: neurogenic bladder dysfunction (1 patient), phase following anti-incontinence surgery (2 patients), simultaneous carrying out of further surgery, such as a hysterectomy or vaginal repair (22 patients). Thus, 53 patients could ultimately be included in the study.

\section{Initial investigation}

The preoperative investigation comprised taking patients' urogynaecological medical history, keeping a micturition diary for at least $2 \times 24$ hours, a pelvic examination, urinalysis, a urodynamic examination and an ultrasound, and required patients to complete both the ICIQ-OAB and ICIQ-OABqol questionnaires in the Czech language. ICIQ-OAB is a validated questionnaire that uses four questions to measure the severity of OAB symptoms (urinary frequency, nocturia, imperative urgency and urge urinary incontinence) and which determines the level of suffering caused by this on an analogue scale. ICIQ-OABqol uses 26 questions to measure the impact of OAB symptoms on quality of life. An overview of the ICIQ questionnaire can be found at www.iciq.net. Both questionnaires used are expressly recommended for use in the context of scientific studies in a review article by V. Khullar [13].

\section{Tape insertion and check-up}

All patients underwent the TVT-O tape procedure (transobturator tape inside-out technique, Ethicon). A check-up took place three months postoperatively: micturition diary for two days, questioning about urge incontinence, urinary tract ultrasound, completing both the ICIQ-OAB and ICIQ-OABqol questionnaires, as well as a consultation regarding the desire for drug treatment of OAB symptoms.

\section{Statistical analysis}

When we speak of being cured with regard to a symptom, this refers to the symptom no longer occurring after tape placement, for example the disappearance of urinary urgency, a frequency of micturition of less than nine episodes per 24 hours, no need to visit the toilet during the night and no more episodes of urge incontinence. Accordingly, the reduced frequency of these symptoms is referred to as improvement. This cure and improvement are indicated in a purely descriptive manner, as is the presentation of the questionnaire scores before and after tape placement. The t-test for paired samples was used to compare the frequency of micturition, as well as the questionnaire total scores before and after tape placement. All analyses were performed using the statistical functions of the Microsoft Excel programme. P values $<0.05$ were considered statistically significant. 


\section{Results}

$\nabla$

\section{Parameters of the initial investigation}

- Table 1 shows the patient medical history data. In addition to age, body mass index, and duration of symptoms, this also includes previous medicative and surgical treatments, medical history of childbirth and risk factors.

- Table 2 gives an overview of research findings following clinical exploration, a urodynamic examination and an ultrasound. These all refer to the patient's condition before tape placement.

\section{Evaluation of micturition diary}

According to entries in 22 patients' (41.5\%) micturition diaries, tape placement reduced micturition frequency to eight episodes or fewer per 24 hours. These patients can thus be described as being cured in relation to urinary frequency ( $\triangle$ Table 3 ). A further 23 patients (43.4\%) experienced an improvement in urinary frequency. Nocturia disappeared completely in only 12 patients (22.6\%), with a further 23 patients (43.4\%) recording an improvement. The largest cure percentage was that recorded in relation to the symptom of urge incontinence, which $83.9 \%$ claimed not to suffer from following tape placement. If we look at all three

Table 1 Patient medical history data.

\begin{tabular}{|c|c|c|}
\hline Anamnestic information & $\begin{array}{l}\text { Number } \\
\text { of patients }\end{array}$ & $\%$ \\
\hline \multicolumn{3}{|l|}{ Age } \\
\hline$>0-50$ & 14 & 26.4 \\
\hline - 51-70 & 31 & 58.5 \\
\hline$>>70$ & 8 & 15.1 \\
\hline \multicolumn{3}{|l|}{ BMI } \\
\hline$><25.0$ & 13 & 25.0 \\
\hline > $25.0-35.0$ & 34 & 65.4 \\
\hline$>35.0$ & 5 & 9.6 \\
\hline D N/A & 1 & \\
\hline \multicolumn{3}{|l|}{ Duration of symptoms (in years) } \\
\hline$><1$ & 3 & 5.6 \\
\hline$>1-5$ & 36 & 67.9 \\
\hline$>5$ & 14 & 26.4 \\
\hline on average & 4.92 & \\
\hline \multicolumn{3}{|l|}{ Previous surgery } \\
\hline - hysterectomy & 13 & 24.5 \\
\hline - anterior colporraphy & 1 & 1.9 \\
\hline$\checkmark$ none & 39 & 73.6 \\
\hline \multicolumn{3}{|l|}{ Anticholinergic drug history } \\
\hline - subjective without effect & 8 & 15.1 \\
\hline subjective with effect & 2 & 3.8 \\
\hline - subjective with temporary effect & 12 & 22.6 \\
\hline none & 31 & 58.5 \\
\hline \multicolumn{3}{|l|}{ History of childbirth } \\
\hline s spontaneous vaginal & 52 & 98.1 \\
\hline - operative vaginal (forceps) & 1 & 1.9 \\
\hline \multicolumn{3}{|l|}{ Parity } \\
\hline$>1$ & 6 & 11.3 \\
\hline$>2$ & 37 & 69.8 \\
\hline$\checkmark 3$ & 7 & 13.2 \\
\hline$>4$ & 3 & 5.7 \\
\hline Taking anti-depressants & 12 & 22.6 \\
\hline Diabetes mellitus & 6 & 11.3 \\
\hline Bronchial asthma & 10 & 18.9 \\
\hline Nicotine abuse & 11 & 20.8 \\
\hline Constipation & 13 & 24.5 \\
\hline Urinary tract infection $>2 \times /$ year & 6 & 11.3 \\
\hline
\end{tabular}

above-mentioned symptoms together, 10 patients (18.9\%) reported the simultaneous disappearance of all symptoms, and the simultaneous worsening of all three symptoms did not occur in a single case.

Table 2 Patient data according to clinical examination, urodynamics, ultrasound.

\begin{tabular}{|c|c|c|}
\hline Parameters & $\begin{array}{l}\text { Number } \\
\text { of patients }\end{array}$ & $\%$ \\
\hline \multicolumn{3}{|l|}{ Prolapse } \\
\hline none & 39 & 73.6 \\
\hline - small cystocele & 9 & 17.0 \\
\hline - small rectocele & 5 & 9.4 \\
\hline \multicolumn{3}{|l|}{ First urgency } \\
\hline - $<150 \mathrm{ml}$ & 11 & 22.0 \\
\hline$>>150 \mathrm{ml}$ & 39 & 78.0 \\
\hline no data & 3 & \\
\hline \multicolumn{3}{|l|}{ Total bladder capacity } \\
\hline - $<350 \mathrm{ml}$ & 14 & 26.4 \\
\hline - > $350 \mathrm{ml}$ & 39 & 73.6 \\
\hline Proven detrusor contractions & 2 & 3.8 \\
\hline Hypotonic urethra (ISD) & 10 & 18.3 \\
\hline \multicolumn{3}{|l|}{ Qmax } \\
\hline$-<15 \mathrm{ml} / \mathrm{s}$ & 3 & 5.8 \\
\hline$>>15 \mathrm{ml} / \mathrm{s}$ & 49 & 94.2 \\
\hline no data & 1 & \\
\hline \multicolumn{3}{|l|}{ Residual urine } \\
\hline - $0-10 \mathrm{ml}$ & 33 & 62.3 \\
\hline - $11-20 \mathrm{ml}$ & 9 & 17.0 \\
\hline - $21-30 \mathrm{ml}$ & 6 & 11.3 \\
\hline - $31-40 \mathrm{ml}$ & 4 & 7.5 \\
\hline$>>40 \mathrm{ml}$ & 1 & 1.9 \\
\hline Urethral hypermobility & 47 & 88.7 \\
\hline
\end{tabular}

* ISD = intrinsic sphincter deficiency as per international guidelines [14,15]

Table 3 Changes in individual symptoms 3 months after tape placement.

\begin{tabular}{|c|c|c|c|}
\hline Symptom & Change & $\begin{array}{l}\text { Number } \\
\text { of patients }\end{array}$ & $\%$ \\
\hline \multirow[t]{4}{*}{ Urinary frequency } & cured & 22 & 41.5 \\
\hline & better & 23 & 43.4 \\
\hline & the same & 7 & 13.2 \\
\hline & worsened & 1 & 1.9 \\
\hline \multirow[t]{4}{*}{ Nocturia } & cured & 12 & 22.6 \\
\hline & better & 23 & 43.4 \\
\hline & the same & 12 & 22.6 \\
\hline & worsened & 6 & 11.3 \\
\hline \multirow{5}{*}{$\begin{array}{l}\text { Urge urinary } \\
\text { incontinence }\end{array}$} & cured & 26 & 83.9 \\
\hline & better & 0 & 0 \\
\hline & the same & 2 & 6.5 \\
\hline & worsened & 3 & 9.7 \\
\hline & $\begin{array}{l}\text { (without urge urinary } \\
\text { incontinence: } 22 \text { ) }\end{array}$ & & \\
\hline $\begin{array}{l}\text { Patients without } \\
\text { urinary frequency, } \\
\text { nocturia or urge } \\
\text { urinary incontinence }\end{array}$ & & 10 & 18.9 \\
\hline $\begin{array}{l}\text { Patients with the } \\
\text { simultaneous worsen- } \\
\text { ing of urinary fre- } \\
\text { quency, nocturia } \\
\text { and urge urinary } \\
\text { incontinence }\end{array}$ & & 0 & 0 \\
\hline
\end{tabular}



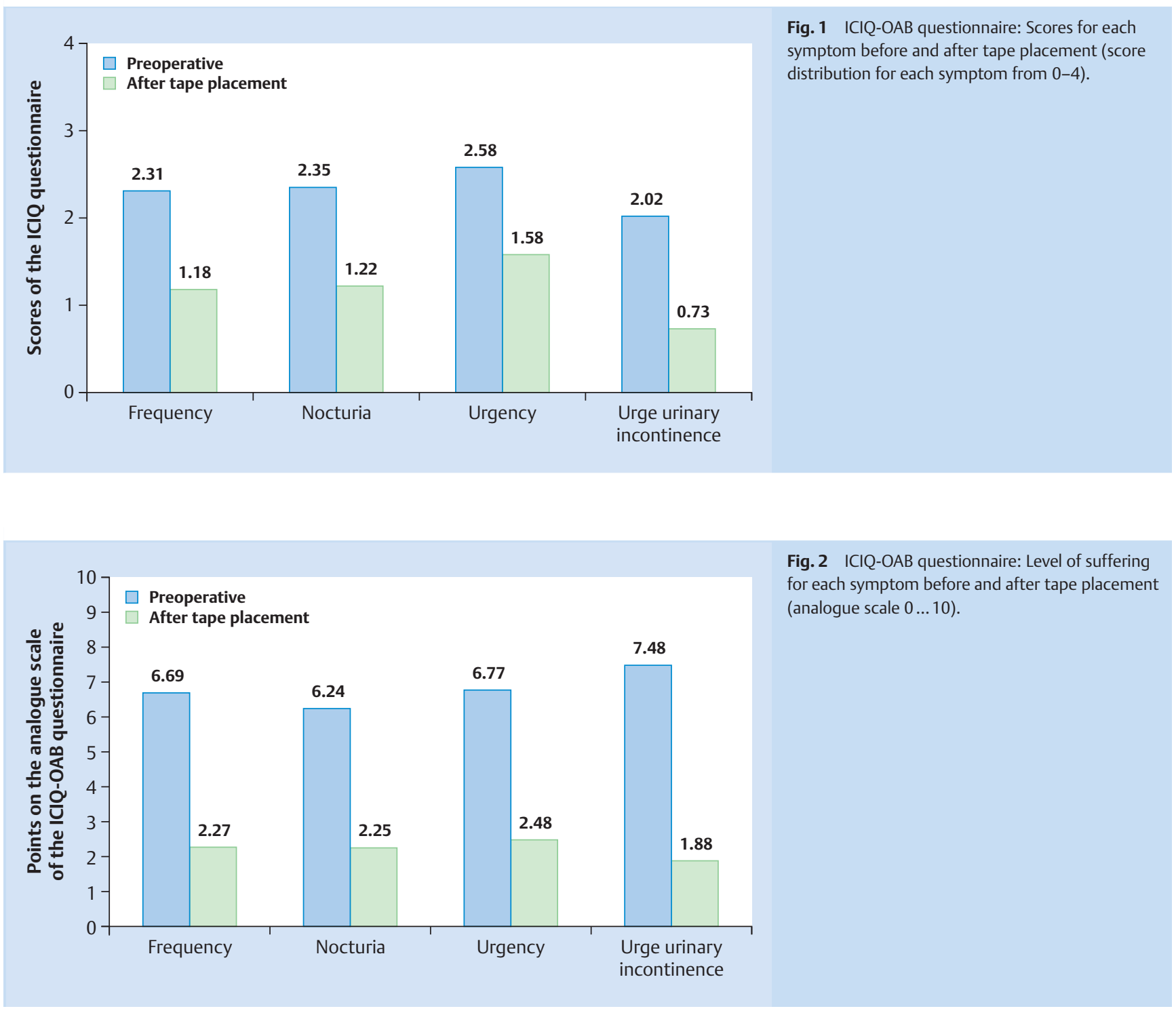

The records in the micturition diary also allow, relative to the entire group of patients, the calculation of an average value of episodes of micturition per 24 hours and per night, and their comparison before and after tape placement ( $\triangle$ Table 4). Prior to tape placement, the average micturition frequency was 16.09 episodes/24 h and 2.16 episodes/night. This was reduced 3 months after tape placement to 10.12 episodes/24 h and 1.07 episodes/ night. The reduction of both values is statistically significant $(\mathrm{p}<0.001)$.

\section{Analysis of the questionnaires}

In the ICIQ-OAB questionnaire, patients were required to provide information about the severity of the various symptoms of overactive bladder syndrome. The mean scores before and after tape placement are shown in 0 Fig. 1. On average, the most pronounced symptom was urgency (average score before tape placement: 2.58, after tape placement: still 1.58). All of the symptoms improved on average, with the greatest improvement being recorded in relation to urge incontinence (score difference: 1.29). - Fig. 2 represents a further result of the ICIQ-OAB questionnaire. In relation to each symptom, patients were asked how much the symptom troubled them. The subjective distress had to be speci-
Table 4 Changes to micturition variables.

\begin{tabular}{|c|c|c|c|}
\hline $\begin{array}{l}\text { Micturition } \\
\text { variable }\end{array}$ & $\begin{array}{l}\text { Before tape } \\
\text { placement }\end{array}$ & $\begin{array}{l}\text { After tape } \\
\text { placement }\end{array}$ & p-value \\
\hline $\begin{array}{l}\text { Frequency of } \\
\text { micturition/24 h }\end{array}$ & 16.09 (SD 4.97) & 10.12 (SD 4.15) & $<0.001$ \\
\hline Nocturia & 2.16 (SD 1.82) & 1.07 (SD 0.96) & $<0.001$ \\
\hline
\end{tabular}

fied on a scale using numbers from 0 to 10 . The highest level of distress was therefore caused by the symptom "urge incontinence" (average of 7.48 on the aforementioned scale), followed by "urgency" (average value: 6.77). The biggest difference in level of suffering values here, i.e. the greatest improvement, was observed for urge incontinence once again (point difference: 5.6). A total score was calculated from the two ICIQ-OAB and ICIQOABqol questionnaires, and these were compared before and after treatment ( $\triangle$ Table 5). The total score fell from an average of 9.25 before tape placement to 4.5 after tape placement for the ICIQ-OAB questionnaire. In the case of the ICIQ-OABqol questionnaire, these values were 77.4 before and 44.2 after tape 
Table 5 Total scores for the respective questionnaire (total score distribution for ICIQ-OAB of 0-12, for ICIQ-OABqol of 25.150).

\begin{tabular}{|lccc|}
\hline Questionnaire & $\begin{array}{l}\text { Before tape } \\
\text { placement }\end{array}$ & $\begin{array}{l}\text { After tape } \\
\text { placement }\end{array}$ & p-value \\
\hline ICIQ-OAB & 9.25 & 4.5 & $<0.001$ \\
\hline ICIQ-OABqol & 77.4 & 44.2 & $<0.001$ \\
\hline
\end{tabular}

placement. In the case of both questionnaires, the total score decreased statistically significantly $(\mathrm{p}<0.001)$.

\section{Need for drug treatment of OAB after tape placement} Finally, all patients were asked at the check-up 3 months after tape placement if they still wished to have drug treatment for any continuing symptoms of overactive bladder syndrome. 15 patients (28.3\%) indicated a desire for this kind of treatment.

\section{Discussion \\ $\nabla$}

It is well known that suburethral tape has been used for the improvement or cure of stress incontinence with much success [16]. The effect on sphincter weakness is well documented in many studies. Our study, however, does not address the variables of stress urinary incontinence, but the symptoms of overactive bladder syndrome, which were present in all patients involved in the study in addition to stress urinary incontinence. In many studies, these frequent accompanying symptoms are not sufficiently taken into account, if at all.

The existing preoperative symptoms of overactive bladder syndrome in all patients involved in the study were significantly alleviated in accordance with the results shown. The level of suffering caused by the micturition problems also decreased significantly after tape placement. In some cases, tape placement led to the worsening of a single symptom of overactive bladder symptom, but in no case did all measured variables worsen simultaneously.

When it comes to the individual components of overactive bladder syndrome, urinary frequency and urge incontinence were improved and cured in 85 and $84 \%$ of cases respectively, while the largest positive change was seen in urge incontinence, which has been reported consistently by Abdel-fattah et al. [7]. The improvement or cure of nocturia, however, was only possible in $67 \%$ of cases. This can certainly be explained by the influence of nocturnal polyuria $[17,18]$, i.e. by increased urine production during the night, which of course cannot be influenced by the manipulation of the lower urinary tract.

How can one explain the positive influence of the suburethral tape on the symptoms of overactive bladder syndrome? D. Perucchini and G. Schär attribute the triggering of the urge sensation to the entrance of urine into the proximal urethra via what is known as funnelling $[5,19,20]$, eliminating the urethra funnel using tape placement could thus lead to the elimination of urinary urgency [21]. Another hypothesis of "urethrogenic detrusor over-activity" states that, in certain cases, detrusor over-activity precedes urethral relaxation, and that patients with this disorder would respond better to surgical treatment and less to antimuscarinic drug treatment [22-25].

Which factors then can prevent an improvement of the symptoms of overactive bladder syndrome through tape placement? The main factors considered here are: hypotonic urethra (intrin- sic sphincter deficiency - ISD), proven urodynamic detrusor contractions, an elevated degree of preoperative symptom severity, and advanced age. The latter three unfavourable prognostic risk factors were already proven $[26,27]$. In addition to these, Gamble [28] also found: two or more episodes of nocturia, a decreased total cystometric bladder capacity, higher detrusor pressure and lower bladder volumes in the occurrence of detrusor contractions, and lower flow rates (Qmax). Katsumi and Rutman [27] conclude from their literature review that transobturator tape placement shows better results in terms of the effect on an overactive bladder than retropubic placement. Further studies are certainly needed for the unambiguous assessment of all of these factors.

\section{Conclusion for Clinical Practice \\ $\nabla$}

The implantation of a suburethral tape can statistically significantly improve not only stress incontinence, but also the often co-existing symptoms of overactive bladder syndrome. This statement applies more to urge incontinence and urinary frequency than to nocturia. The study compares the situation prior to, and three months after TVT-O tape placement. Quality of life is significantly increased.

\section{Conflict of Interest \\ $\nabla$}

None.

\section{References}

1 Abrams $P$, Andersson KE, Birder $L$ et al. Fourth International Consultation on Incontinence Recommendations of the International Scientific Committee: Evaluation and treatment of urinary incontinence, pelvic organ prolapse, and fecal incontinence. Neurourol Urodyn 2010; 29: 213-240

2 Dooley $Y$, Lowenstein L, Kenton $K$ et al. Mixed incontinence is more bothersome than pure incontinence subtypes. Int Urogynecol J Pelvic Floor Dysfunct 2008; 19: 1359-1362

3 Frick AC, Huang AJ, Van Den Eeden SK et al. Mixed urinary incontinence: greater impact on quality of life. J Urol 2009; 182: 596-600

4 Cox A, Herschorn S, Lee L. Surgical management of female SUI: is there a gold standard? Nat Rev Urol 2013; 10: 78-89

5 Tunn R, Hanzal E, Perucchini D, Hrsg. Urogynäkologie in Praxis und Klinik. 2. Aufl. Berlin: de Gruyter; 2010: 232

6 Kissling J, Westermann L, Agarwala N. Resolution of urge urinary incontinence with midurethral sling surgery in patients with mixed incontinence and lwo-pressure urethra. Gynecol Surg 2012; 9: 427-432

7 Abdel-fattah M, Mostafa A, Young D et al. Evaluation of transobturator tension-free vaginal tapes in the management of women with mixed urinary incontinence: one-year outcomes. Am J Obstet Gynecol 2011; 205: 150e1-150e6

8 Jain P, Jirschele K, Botros SM et al. Effectiveness of midurethral slings in mixed urinary incontinence: a systematic review and meta-analysis. Int Urogynecol J 2011; 22: 923-932

9 Athanasiou S, Grigoriadis T, Giannoulis G et al. Midurethral slings for women with urodynamic mixed incontinence: what to expect? Int Urogynecol J 2013; 24: 393-399

10 Palva K, Nilsson CG. Prevalence of urinary urgency symptoms decreases by mid-urethral sling procedures for treatment of stress incontinence. Int Urogynecol J 2011; 22: 1241-1247

11 King A, Rapp ED. Short term urgency outcomes following transobturator midurethral sling placement. CJU 2011; 18: 5796-5801

12 Yoo EH, Kim D. Predictors of postoperative antimuscarinics in women with mixed urinary incontinence after transobturator surgery. Int Urogynecol J 2013; 24: 401-406 
13 Khullar V. Patient-reported outcomes and different approaches to urinary parameters in overactive bladder: what should we measure? Int Urogynecol J 2012; 23: 179-192

14 Ghoniem G, Stanford E, Kenton K et al. Evaluation and outcome measures in the treatment of female urinary stress incontinence: International Urogynecological Association (IUGA) guidelines for research and clinical practice. Int Urogynecol J 2008; 19: 5-33

15 Tunn R, Hanzal E, Perucchini D, Hrsg. Urogynäkologie in Praxis und Klinik. 2. Aufl. Berlin: de Gruyter; 2010: 119

16 Naumann G, Kölbl H. Current developments and perspectives on the diagnosis and treatment of urinary incontinence and genital prolapse in women. Geburtsh Frauenheilk 2012; 72: 202-210

17 Cornu JN, Abrams P, Chapple CR et al. A contemporary assessment of nocturia: definition, epidemiology, pathophysiology, and management - a systematic review and metanalysis. Eur Urol 2012; 62: 877890

18 Van Kerrebroeck PEV, Dmochowski R, FitzGerald MP et al. Nocturia research: current status and future perspectives. Neurourol Urodyn 2010; 29: 623-628

19 Murray S, Lemack GE. Overactive bladder and mixed incontinence. Curr Urol Rep 2010; 11: 385-392

20 Jung SY, Fraser MO, Ozawa $H$ et al. Urethral afferent nerve activity affects the micturition reflex; implication for the relationship between stress incontinence and detrusor instability. J Urol 1999; 162: 204-212
21 Dmochowski R, Staskin D. Mixed incontinence: definitions, outcaomes, and interventions. Curr Opin Urol 2005; 15: 374-379

22 Koonings P, Bergman A, Ballard CA. Combined detrusor instability and stress urinary incontinence: where is the primary pathology? Gynecol Obstet Invest 1988; 26: 250-256

23 Wise BG, Cardozo LD, Cutner A et al. Prevalence and significance of urethral instability in women with detrusor instability. Br J Urol 1993; 72: $26-29$

24 Koonings PP, Bergman A. Urethral pressure changes in women with detrusor instability. Bladder or urethral pathologic process? Urology 1991; 37: 540-542

25 Major H, Culligan P, Heit M. Urethral sphincter morphology in women with detrusor instability. Obstet Gynecol 2002; 99: 63-68

26 Lee JK, Dwyer PL, Rosamilia A et al. Persistence of urgency and urge urinary incontinence in women with mixed urinary symptoms after midurethral slings: a multivariate analysis. BJOG 2011; 118: 798-805

27 Katsumi HK, Rutman MP. Can we predict if overactive bladder symptoms will resolve after sling surgery in women with mixed urinary incontinence? Curr Urol Rep 2010; 11: 328-337

28 Gamble TL, Botros SM, Beaumont JL et al. Predictors of persistent detrusor overactivity after transvaginal sling procedures. Am J Obstet Gynecol 2008; 199: 696.e1-696.e7 